\title{
WHO IS BOSS IN YOUR SHOP?
}

\author{
By Morris Llewelly Cooke, \\ Consulting Engineer, Philadelphia.
}

The European War has developed into a high-powered advertisement for community organization, for the scientific in management and even for capacity in the individual. Notwithstanding much that might be cited to the contrary, our great national desire is to be efficient in both government and industry. Individually and as a people we are almost relentlessly seeking the bases of such Effciency; and we use the word capitalized as a synonym for the maximum of considered well-being. This can be affirmed notwithstanding what appears to be the most conspicuous fact in our current industrial development, i.e., that more and more our people refuse to be efficient beyond their own desires. As the late Robert G. Valentine expressed it-perhaps a bit more emphatically than is warranted by developments to date- "the days of compulsion-the days of service without consent-are over. . . . . In all those areas of life wherein man deals with man great breaches have been made in the ranks of compulsion." But it would be a great mistake to assume either that this greater liberty of action demanded by the individual necessarily makes for inefficiency or that it acts as a challenge to individual as opposed to group leadership.

Apparently the New World has little to gain from any blind copying of foreign models in this matter of industrial organization and control. German efficiency both in government and industry depends on a philosophy absolutely inconsistent not only with American traditions but with American ideals. In view of the virtual abandonment "for the period of the war" of the fabric of industrial practises and mechanisms built up in Great Britain during two generations largely by the labor unions, we are warranted in viewing what was the British industrial system with something more than suspicion. Are we not warranted in the belief that there is in the making in America a scheme of direction and control hoth for government and for industry vastly more efficient and at the same time vastly more democratic than has heretofore been deemed possible? 


\section{Some Aspects of American Superionity}

American life has a decided advantage over that on the continent or in Great Britain in the more numerous points of contact between groups-if indeed there is not with us a more genuine understanding between classes. Then, notwithstanding much that at times seems to argue against it, is there not among our people a deeper response of the individual to the Authority within himself than is to be found among other peoples? With these two points in our favor and when as a nation we have grasped more completely the significance of that union within industry of science and coöperation which we call scientific management, may there not be brought about an American efficiency-at once an expression of the individualism of our forefathers and the vehicle for our more recent collective aspirations? The sanctions of this system will not be militaristic as are those encountered even on the industrial side of German life. It will avoid the pitfalls of that type of group action which is so largely responsible for "muddling" in the United Kingdom. And we have the right to expect that pervading its every activity there will be something of the spirit-the élan of the France of our dreams and of present-day realities.

We Americans cannot put our trust in the much heralded German efficiency for it gives us a kind of science but no genuine cooperation. Science without coöperation is a relatively lifeless thing. America's high calling is to prove for our common humanity that there is a method of production growing out of individualistic leadership coupled with an essentially democratic control which is not only more conducive to race-happiness but which in its very nature is scientific and is designed to outstrip any system which is the outgrowth of a military or an autocratic régime such as is found in Germany. Military efficiency, it must be remembered, consists largely in the ability to mass the greatest possible strength at a given place at a given moment. Industry on the other hand struggles rather for steady performance. Peaks or depressions in either demand or output in industry are to be regretted. The "supreme moments" of the battlefield are taboo and even spectacular campaigns rarely result in permanent improvement. 


\section{The Movement for Industrial Democracy}

We can admit that the movement for industrial democracy in this country in its more obvious aspects has been largely away from rather than toward science and coöperation. But there are reasons for believing that the organized labor movement in the United States must in the near future dig itself in along a front somewhat different from the one it has occupied in England, and by reflection in this country, for a generation or two past. Some at least of the faces of this new formation seem reasonably clear.

Two men having formed a partnership may adopt any one of three plans for the conduct of the enterprise. One of the partners may be put in supreme command, expressed or understood, or all matters of moment can be decided by joint action, or there may be an assignment of function as between the two partners so that one is supreme in say selling and finance, while the other has the final decision as to manufacturing. This is a statement in very simple terms of a problem common to all management. Upon the relation thus established between the individual and the group depends the conduct of a city or a nation, of a single manufacturing establishment or of an industry.

A partnership of two men is admittedly a simple form of human coöperation, but immediately the question of individual versus group direction and control presents itself. To enlarge this group from two to the hundred millions of population in the United States does not alter the underlying philosophy or interfere with the scientific determination of the proper field in which group and individual action should each operate.

Government began with the unhampered will of the strongest single individual and under democracy's warming influence has broadened out until larger and larger groups eventually control political action. In this transition from a régime in which the administrative program of an individual was enforced by the selfsame individual, to the present time where in matters of governmentif not of industry - all administration is supposed to find its warrant in the consent of the governed. We have not always made the sharp distinction which appears necessary between the administrative code itself and the authority which vitalizes it into action. The democratic ideal would appear to be administration by indi- 
viduals with collective pressure when necessary, rather than too much insistence on the part of individuals.

\section{Some Recent Pouitical and Industrial Tendencies}

Recently there has been noticeable in the political thinking of the United States a demand for at least a partial return to administrative individualism as evidenced by movements favoring the short ballot, the city manager, longer terms for administrative officials, centralized responsibility, smaller legislative bodies, and the substitution of judicial decisions for those of juries in certain classes of litigation. In our political democracy we are beginning to admit that efficiency comes through giving authority to individuals and requiring performance from them. The initiative, referendum, and recall are simply some of the checks and safeguards which are essential parts of this scheme of management in its application to government.

Scientific management stands for the same tendencies in industry. It recognizes that one fact may invalidate a hundred opinions. Scientific management seeks to set off the territory in which, because the facts are obtainable, action can be determined by the facts rather than by caprice. A fancy, whether it be the fancy of one or of a million, is still a fancy. We cannot vote a fact. Action by opinion ebbs and flows while action based on the facts can be reasonably consistent and permits of logical and continuous growth. The truth does set us free.

In our scheme of industry and of government the distinctions between these two territories-one of law and the other of judgmentwill become more apparent. Collectively we shall gradually learn to trust individuals to read the facts. We may in time class many of these individuals as experts and ultimately revere them. Nor need we abandon the scheme because we are occasionally betrayed by misjudged abilities and limited vision. On the other hand the democrat will not be asked to vote once a year on town clerks or minor bond issues. Rather each hour in the day in industry and in life he will render his judgments made all the more necessary in a world broadened by the discoveries of science and deepened through our quickened insights and appreciations. 


\section{Labor Union Attitude Differs}

While the tendencies in our political democracy seem to be in the direction of a larger degree of individualism, certainly in that part of the labor movement which has become organized no such drift is as yet to be observed. According to what appears to be the code of the labor unions and of some of their most distinguished advocates the most satisfactory way to settle almost any given question is to vote on it. If by its very nature it cannot be voted on it must then be deprecated. Democracy and voting are, under this dispensation, synonymous terms. It may be easy to prove that the leaders of the American Federation of Labor do not hold to this very consistently as a general philosophy of life but nevertheless it colors most of the relations of organized labor to the public. In fact the growing demand for what has come to be known as "consent" under the most frequent interpretation seems to involve a maximum of group action rather than a maximum of action by individuals. "Consent" as nearly as I can make out involves a much broader application of the theories underlying collective bargaining. Our activity and loyalty even in minor matters is to be secured only after a collective measuring of the pros and cons.

The collective bargain has found its field principally in the agreements between individual employers and their employes and has concerned itself largely with hours and wages and only secondarily with the other conditions surrounding employment. "Consent," on the other hand, seems to involve much broader relationships of the group which work for wages to government, to industry and to society. The relatively primitive struggle for higher wages and shorter hours gives way in a sense to a struggle for standing. Minor claims such as those for compensation on account of injuries are superseded by a claim to a share in the conduct of the business whether it be a manufacturing establishment, an industry, a city or a nation. I am picturing this widening of the front of the labor propaganda not because I lack sympathy with it but only to question the one phase which puts a premium on group administration and group decisions.

It may seem axiomatic that because in working out our political democracy we have been in the habit of expressing through the vote our collective pleasure on all kinds of matters-questions of judgment as well as questions of fact-that therefore we must necessarily pass through a similar period in working out our industrial 
democracy. But possibly we in America can, because of our growing respect for science and our dedication to coöperation, work out a system by which those who work with their hands and their heads and those who represent property interests will each have their proper share in the conduct of industry and in its rewards and this without the necessity of resorting to a vote on the length of a mine car, the proper shovel load for a day laborer or the use of instruments of precision such as the stop watch.

\section{Significance of the Demand for "Consent"}

The growing demand for "consent" as voicing a natural reaction against a too autocratic control in industry is to be welcomed without any reservation. But if "consent" necessarily implies an unwillingness to follow the individual-except after a vote-and substitutes everywhere group action, we will most certainly have stepped from the frying pan into the fire. For it is only through individuality in management that we guarantee to society the maximum of production and bring to each worker the largest possibility of joy in his work and, more important still, keep free the human spirit for those adventures without which it were better that this old world of ours should grow too cold for human habitation. As Robert B. Wolf has said, "the function of the group should be the greatest possible amount of freedom for the development of the individual." Industrial democracy has forged the collective bargain to act as one check against the excesses of individualism. But we must be careful lest the check be used, as some of our political checks have been used, to destroy all chance of positive and strong and timely action.

One of the principal indications of an impending shift in the front of the labor movement in this country is found in the fact that many of labor's foremost spokesmen admit that in increased production lies one of the most hopeful routes to a higher social and economic status for those who work with their hands. In several recent reports-largely influenced by the American Federation of Labor-where this question of the effect of increased production was distinctly raised, labor's representatives refused to oppose increased production as such. This is a far step from the "Ca canae" and "soldiering" recently and openly advocated and practiced. The laboring classes were of course partially forced to such resorts 
by the attitude of boards of directors in refusing to administrative officers the right to pay to especially proficient workers high wagesor at least to pay wages much above the district scale.

Scientific management stands first, last and all the time for increased production. But production is interpreted in the broadest fashion as including everything that makes for human happiness. Thus Marshall points out that art and even the concepts of the mathematician may be production in the very highest sense. Scientific management holds that equal opportunity and liberty itself are aids to production, that poverty is unnecessary and that labor does not even approximate being a commodity.

Anyone who doubts whether this matter of "consent" is to be pressed should read recent articles on the subject which have appeared during the last few years in some of our leading periodicals ${ }^{1}$ over the signatures of Justice Louis D. Brandeis, Minor Chipman, the late Robert G. Valentine, John P. Frey, secretary of the Iron Moulders Union, Felix Frankfurter, Robert Bruère, and the late Robert F. Hoxie. One finds of course even among this group of writers considerable variety of opinion as to the means which it will be wise for the laboring classes to use in giving voice to "consent." But no one of them apparently has much faith in the possibility of a fairly rigorous individualistic administrative policy that is to be protected and even induced under group control.

This whole question has been brought to a focus recently through the passage by Congress of legislation absolutely prohibiting premium payments and the use of the stop watch in several important branches of the government service. At the last session strenuous efforts were made to broaden the field for this legislation so as to include all classes of government work. Of course these are only preliminary skirmishes in a legislative campaign, whose real object is to forbid the use of these aids to a genuine science of industry in all establishments having government contracts, and finally to include industrial establishments generally.

At least one large national association of artisans-the electrotypers-have recently established a uniform selling price for the

'See especially the discussions in the Bulletin of the Taylor Society to promote the science of management. Dr. Harlow S. Person, Dean of the Tuck School of Dartmouth College is president of the Taylor Society and H. W. Shelton, Hanover, N. H., is secretary. 
product on which they work. With both the wages to be paid by the employer, and the prices which he may charge for his product fully determined by group action and virtually by the organized labor group, it will be admitted that a radically new industrial situation will have been created. The field for "consent" will have been materially widened.

Everyone seems convinced that we are on the threshold of some very considerable readjustments in our American industrial world. It is entirely possible that present tendencies may become emphasized. But it seems equally possible, that organized labor will in the immediate future discover the futility of some of the remedies which are being pushed today with the utmost enthusiasm-administration by groups rather than by individuals among the number.

Perhaps the most obvious mechanism of group action in industry, as it is in government, is the committee. My views on committee management have been fairly adequately expressed in $\mathrm{Aca}$ demic and Industrial Efficiency published by the Carnegie Foundation for the Advancement of Teaching. But there are two additional points that should be made. In almost every instance which has come to my attention in which a committee in a factory was supposed to have full responsibility it had in reality very little. A shop committee has responsibility only when it pleases those who hold the purse strings to let it have its way. A committee may decide 999 things out of 1,000 , but the fact that the members of the committee are kept from deciding the last one, and of course the critical one, keeps them from having the same kind of responsibility which the owner of a business has. Authority with such a string to it is not what is really meant by "consent." Employers should not flatter themselves that workingmen confuse committee control with genuine industrial democracy. It is of the essence of democracy, whether political or industrial, that it shall be motived from below and not dictated from the top.

\section{Limitations in Application of "Consent"}

Under any reasonably modern or discerning attitude toward industry it must be conceded that in those things we do and in which we ask the worker's coöperation we must have his permission or "consent." But care must be taken to see that in freely granting 
this contention we do not appear to be advocating something that is unthinkable. No surgeon, for instance, would operate on Samuel Gompers for appendicitis without the latter's permission. But once having secured Mr. Gompers' "consent," no reputable practitioner would permit him to dictate as to instruments or methods. In thus placing himself in the hands of this type of expert, surely Mr. Gompers does not feel that he compromises in any way his independence.

All workers from the top to the bottom are entitled to essentially the same treatment and consideration. I wish the opportunity to say whether I will or will not. I cannot logically deny this to anyone else. Nietzsche says, "Whoever has inflicted upon you the law from without has degraded your moral individuality." It is not desirable to have a man do a thing merely because I tell him to do it. Obedience is rather a primitive virtue. I wish my associates to assume that $I$ am sincere in wanting them to do only those things which they elect to do after as full an acquaintance with the facts as the conditions under which the work must be done makes possible. It very rarely occurs that things fail of the doing on account of this attitude. In other words, "consent" may be interpreted as something larger than the opportunity to vote on each individual problem. Perhaps someone asks what we are to do with the socalled malcontent and kicker. An inquiry as to why such a one is discontented might develop the answer to the question. But even if it does not I am not sure but that any workshop is better for an occasional disgruntled employe. They are not so disposed every hour in the day. The task of winning them puts everybody on guard. One or two cats are not undesirable in a workroom, although it will be admitted that too many members of the feline family might interfere with the even flow of the work.

Is "consent" in reality always a collective matter-does it always involve group action or can it on occasion become a matter of the individual entirely? May we with safety allow this individual "consent" to apply broadly to a field involving not one, but an indefinite number of decisions? Similarly may it not be possible to make individual "consent" operate not only for the moment but throughout a period of time during which many decisions will be reached? These do not seem to be concessions antagonistic to a proper self-respect on the part of the individual worker nor to the 
solidarity of the working classes nor in fact to the maximum of industrial freedom and democracy. But these conditions are vitally essential if we are to develop genuine American efficiency. Each day the discoveries and developments of science make the opposite course increasingly unthinkable. It is hard enough today to keep pace with the possibilities of progress with functionalized management, which of course means the leaving of final decisions in each function to one man rather than to a group. But in the immediate future it is going to be very much more difficult. You will recall Mr. Taylor's prophecy that within two generations there would be 50,000 books on industry for every one we have today. Hugo Münstenburg says in Psychology and Industrial Efficiency: "In a large manufacturing establishment the manager assured me only recently that more than half a million different acts have to be performed in order to complete the goods of that factory." This may have been an exaggeration but I know of no industry where the operations are not in the hundreds of thousands. To hold that we can permit every move in an industrial plant to be submitted to a vote simply shows a lack of understanding of the game of industry.

\section{Proper Relations Between the Group and the Individual}

The cause of popular rule in this country and elsewhere seems to depend upon the correct decision as to the broad question of the group versus the individual. The system demanding one king gives way to a system of many kings-kings of the counter, kings of the lathe and loom-all kings, but only by virtue of superior knowledge. They know. But the reign of each is dependent upon the general acceptance of the individual's right to decide on facts and conditions. Our progress, and even our security, seems to lie in having the vast majority of judgments rendered by the informed individual.

Should we not learn in every relation in life to follow the lead of the particular individual who is charged with any given function, whether he be the President of the United States, the traffic officer, or the clerk in the office? We must not only follow these leads, but use our influence to have others do the same. On the other hand, should we not train ourselves to perform one or more functions so efficiently as to command the respect and loyalty, and reasonably willing service of those upon whose support we are dependent for success in the accomplishment of the work in hand- 
the earning of our livelihood and whatever success we are to achieve. I personally wish to live in a world where it is possible for me to conduct myself along these lines and in which everybody else shall have the same opportunity. This will never be possible in a world run by shop committees or determining boards, or by labor unions, especially if the latter are so organized that everything has to be decided by group action. Both as affecting the individual and the nation, the developement of real democracy depends upon utilizing the high power of individual action, coupled with all the safeguards that can be erected through appeal, investigation and review, and the freest possible publication of results, with the final action based on the judgment of the governed.

I do not wish to have any misunderstanding about my attitude toward the responsibilities and the rights of individual employes. I believe that the most important function of management is to develop within the factory an educational system designed to get every employe "going from within so that he will run himself," in order that he may gradually assume a larger and larger share in the general conduct of the business. "We want all along the line," to quote H. B. Drury, "not only men who can do what they are told to do, but men who can do things we would never think of ourselves. We want men who have enough interest, and education, and experience and boldness, to make positive contributions to the intelligence and vigor of the work." This requires something more than lip service and hand service. It means head service and heart service.

To ask committees, however, to pass constartly on matters about which by the very nature of things they can have at best a minimum of information, is like giving unbridled liberty to a boy because you want to make a man of him. It is demoralizing to any man to be given the opportunity to deliberate and to decide on matters when he is without sufficient education and special preparation and an adequate fact basis, for a scientific decision. I believe in advisory committees, but in each function of the administration the final decision must be made by the individual. Nothing must prevent the individual from making decisions whenever in his judgment the time to decide has arrived. Decisions must be open to the fullest possible investigation and review, followed by a reversal of the decision if the facts reinterpreted so dictate. 
There is one fact connected with industry which requires special consideration. Very few people, either in the labor ranks or out of them really wish to assume or are able to assume broad responsibilities. The work of the future will be to teach people to be eager to assume responsibility and to coöperate effectually. And this cannot be brought about unless the worker is inspired with joy in his task. Hereafter the Captain, whether of industry or of government, will necessarily be the man who loves, and loving, understands, and understanding, builds and leads and inspires great numbers of his fellows.

\section{Weakness of Commission Regulation of Industry}

Since the discussion of the eight-hour day for railroad employes became acute, we have heard a good deal about the possibilities of relief from such situations through wage boards and industrial commissions. To advocate any such regulating agency in this field at the present time is simply to say "Let George do it!" It is not a solution. Let me quote four typical and random paragraphs from recent orders ${ }^{2}$ of the New South Wales Industrial Commission to give you an idea how industrial regulation by commission works:

a. If the work required of them is not in accordance with the general custom of the trade, and is not covered by the definition in clause 8 of the award the drivers cannot be compelled to do the loading and unloading.

b. The rate prescribed for a driver of an engine with a cylinder under 12 inches in diameter is $1 s .4 \frac{1}{2} d$. per hour. Nothing extra need be paid to a driver who is required to clean windows, etc., but the rate mentioned must be paid in any event.

c. An assistant is an employe other than a pastry cook, packer, apprentice carter, or motor-wagon driver as above defined and who does any or all of the following work, viz: bring in raw material; wash, clean and grease pans, tools, tins, and other utensils; clean and wash machines; label tins and boxes; wash and sugar goods; wrap cans and pastry; crack eggs; clean fruit and cut peel; put on and take off peels; attend reel, traveling and draw-plate ovens, provided that a journeyman is in charge; place goods into and take goods from tins, trays, pans, trucks, racks, bins and cupboards, before, during and after the manufacture; pack goods in bakehouses; clean bakehouses, yards and premises, feed and take from machines, put on and into and take from tins, trays, and pans any goods in any stage of their manufacture; top and bottom pies.

${ }^{2}$ The New South Wales Industrial Gazette issued (monthly) by the Department of Labor and Industry, Vol. X, No. 4. August, 1916. Pp. 685, 721, 845, 872. 
d. Men working in wet places are to be paid 1s. per day extra irrespective of the time so engaged. Note-Such wet places are to be determined and declared to be such by the employer and employe by mutual arrangement. In the event of the parties failing to agree it shall be referred to the chairman of the board for his decision.

It should be a matter of deep concern that except for the labor unions there are almost no routine agencies in American industry through which may be obtained an expression of shop opinionindividual and collective. The typical employer claims that he knows what his men think. But as a matter of fact it is as impossible to get the real attitude of mind of a worker or a group of workers from the employer as it is from the labor leader. The machinery through which complaints can be safely made and shop justice gradually established is yet to be devised. As new problems will always be coming up, the settlement of present ones is first of all necessary. The struggle must be to keep at a minimum matters on which debate is desired. The effort must be to anticipate any proper demand of an individual worker or group of workers as to hours, wages, or anything else. To plan for this kind of thing is the function of the highest officers of a company. The average foreman is too preoccupied with the day's work to do it.

\section{Coöperating With the LABor Unions}

The labor unions have for years been quoting Carlyle in using the words "Organize, organize, organize." Without going further they are misquoting him. However, when Frederick W. Taylor wrote Coöperation into the world's industrial creed and into the mechanisms of industry, he altered - and to an extent weakenedthe argument for organization as this has been practiced by labor unions in this country and more especially in England.

To admit a labor union to a plant not previously unionized of to go through the forms of coöperating with one already there does not necessarily mean coöperation in the sense in which $\mathrm{Mr}$. Taylor used it. Sometimes it is easier to admit a union than to keep it out. Again it may be easier to appear to coöperate than to reveal an actual attitude of opposition. The fundamental test is not whether you have unions or do not have them. In some sections of the country and especially in the larger industrial establishments the complete absence of unions would indicate something peculiar in the man- 
agement. It is equally true that most manufacturers having unions and taking credit therefor are claiming something to which they have slight title. Ninty-nine manufacturers out of one hundred who have unions have them only because they cannot help themselves.

I have heard of one plant in which the employes are treated in enlightened fashion that was forced by pressure of a peculiar kind exerted from without the establishment to go through the forms of unionizing on practically the standard basis because as the national leaders said it was such a good place to work that the very fact that it was a non-union shop constituted a constant reflection on the organized labor movement. This means that employers who treat their employes in the matter of wages, hours, safety appliances, etc., even below the average may easily be immune from labor agitation while those who study and even sacrifice to produce improved conditions become the more liable to interference on the part of organized labor.

If scientific management stands for anything it stands for cutting out the "bunk" in every relationship. It is a mockery to call anything short of this scientific. I can understand acquiescing quite wholeheartedly in the establishment of one or more typical unions in my shop. I can even picture myself sitting down and planning with their leaders for their establishment. But I am quite sure that if the objects of these unions and more especially their methods were those that I frequently see advocated in organized labor circles I would have an understanding on one of two bases. Either it would be mutually understood that the unions came there on sufferance ańd because I could not prevent it without making an undue sacrifice, and in spite of my being out of sympathy with their objects and methods, and that I thought the members who paid their dues got almost nothing for their money, or we would have such a mutual understanding as would provide for our working out between us a new kind of a labor guild which I would hope would have quite as much cohesiveness as the old, but would give to the members in return for the money and effort expended a larger recompense in the best things of life.

An employer should welcome every possible check on his honesty of purpose, breadth of view and genuine efficiency. The solidarity of the employes is one of those checks which every right- 
minded employer should both covet and cultivate. But to advocate in industry a type of labor unionism which prohibits the use of the stop watch and the payment of rewards for high performance is to advocate ultimate industrial slavery-however novel the type. A labor union propaganda which does not provide for constant experimentation and the encouragement of new types of organization is short-sighted and not big and broad enough to hold within itself the germ of a republic both politically and industrially free. Research should be as vitally necessary to the wise solution of the problems of labor as to those in other fields of human endeavor.

The labor movement must inevitably seek a new alignmentalong which efficiency will become one of labor's own demandseventually its cardinal demand. The employer who clings to an antiquated machine or one whose system of management is not of the best will ultimately be as obnoxious to labor as are today those who work long hours and pay low wages. In the Great State production will be made a part of the responsibility of labor. And here is where coöperation comes in. Because, as Taylor has pointed out, you can drive men into working hard but it is impossible to drive them into working efficiently. The friends of labor are sometimes tempted to fear scientific management simply because it is efficient. Formerly the New Statesman and sometimes our own Survey have viewed it as a chain newly forged about labor's neck. Such an attitude fails to take into account the fact that true Scientific Management is a closely articulated, delicately adjusted mechanism such as is clearly impossible in an atmosphere of dissatisfaction and discord. It cannot be built out of collective bargaining, even though individual and collective consent are inherent in its practise.

\section{Responsibilities of Leadership}

Do not let us put the onus of reform on the already overburdened workers of the world. If men ever learn to work together and live together efficiently and happily it will only be as we develop a new technique for the individual, yes, a new reverence for the individual. But this is only indirectly the problem of the group or the mass or the "mob" if you must call it that. The responsibility for leadership lies first, of course, at the door of the leader. In the development of a true leadership lies the great hope of democracy- 
whether it be political or industrial. Only through enlightened leadership can we establish a proper relation of the group or mass to the individual, and the leader is he who points the way and pushes on and gaining one eminence uses it only as the basis from which to climb higher.

We can be reasonably sure that the leadership of the future will be far removed from the military ideal which has stood civilization in good stead to date. Even in military affairs it begins to look as if we would hear less about the martinet and more of the man with genuine knowledge, imagination and enthusiasm. I rather think that for the highest efficiency we have too little instructing and too many instructions in industry and business. We work on the fiction that an instruction once issued is carried out to the letter. As a matter of fact most instructions, especially in the higher and therefore more important reaches of industry, are only imperfectly understood. Then again each worker in the last analysis executes only that part of what he understands to be his instructions, which he feels to be essential. Occasionally he does something because he is afraid not to do it. Now if you make a practise of never issuing orders as such it puts it up to you to keep your man convinced. The result is, your associates in practise actually carry out what has become their own purpose as well as yours. You undoubtedly lose here and there-especially in the matter of military precision. But your gains are infinitely greater than your losses. Notice is given to your associates that you do not mind being shown wherein you are mistaken and do not expect anyone to do the foolish or inefficient or dishonest thing simply because it was your order or he thought it was your order to do it. So commands make way for orders, and orders for instructions and instructions for information for employes. The argument is in no wise weakened even if we admit that this system "has still to establish its mutual disciplines and possess its mind," to borrow a phrase from H. G. Wells. It will become increasingly difficult for concerns operated on anything like a military basis to attract to their employ the best class of employes. Industry and government today can have in them adventure and romance-in fact must include both if they are to be properly conducted. More and more our young men of promise will demand the opportunity to associate themselves with industrial undertakings dominated neither by the anti-efficiency 
propaganda of the English labor unions nor by the militaristic know-nothingness of certain types of big business.

\section{Qualities Needed for Leadership and Coöperation}

To analyze the leadership of the future we must recognize in it a twofold quality. We are told that there can be no sound where there is no ear to hear. In some such sense it is true that there can be no leadership if there are none to follow or if none follow gladly. This following is just as important as the leading. To be a leader a man or a woman must first know-know what his job is and then have the experience, the ability, the judgment, the enthusiasm and the vision to execute this allotted task. Just that has been enough to "get many a man by" in the past. But the time has gone when it is enough. It will become increasingly necessary for the leader of the future to be able to visualize these facts and capacities to his several constituencies. As the group widens and the interests of the individual deepen this becomes a more and more difficult task but one to which the powers of the truly great will be attracted.

For the followers there is also a twofold duty, for it is upon them in the last analysis under any democratic scheme that even the ablest and most versatile leader must depend. First we of the mass must learn to be discriminating as to our leaders-we must know more and more about the work of government and more and more about the methods and objects of industry. Otherwise we are ever at the mercy of the charlatan. But beyond this there is a second and most important function of the crowd. We must command the means of making our support effectual. It is not enough to recognize the superintendent of our shop or a President of the Republic as a good and efficient man. We must learn how to make these leaders feel our support and to make our associates know of it. If democracy demands leadership to make it efficient then democracy will be a failure unless we can bring about these conditions without which individuality in management becomes unworkable.

Whether we like it or not, the day has gone by when a leader of men can afford to neglect any opportunity of getting himself and his work placed fairly before his public. But he must do more than this. He must in many instances create these opportunities for 
visualizing to the mass of the people his activities and those of his associates. There is so much that is distorted and untrue said about anyone doing important work that the mere desire to offset and neutralize this misinformation requires much educational work. The times and the conditions of both government and industry and the needs of society demand even more than this. It is not enough for the officer of a company or the superintendent of a shop to be honest, active and able. He must make his associates know this. He must keep his constituency convinced and with an ample factor of safety. If we are to have coöperation we must have genuine, relentless publicity affecting every relation.

The picture of a frock-coated and portly gentleman sitting solitary and silent behind a roll-top desk in the front office during those rare intervals between meetings at the bank and at the board of trade is no longer our symbol for industrial leadership. We demand more and more frequent points of contact with our leaders, we prefer to be the president's associates rather than his men. The sphinx is increasingly at a disadvantage in comparison with the man who can place his cards on the table. Whether it be for the employer of 5 or $50,5,000$ or 50,000 makes little difference-self-revealment, incessant and studied, but above all true to the facts-has become the great moving force. Science is beginning to illumine all the work of men. Everywhere, even in the humbler daily tasks, she provides an art. Our industrial relations are no longer for the isolated plant only. They are trade-wide, industry-wide, nation-wide, yes worldwide. Into this maze, if men would tread with freedom, love must enter. The dream will never come true through collective bargaining alone.

You-our leaders in government and in industry - take notice! If you force us to it we will run the ship-whether of industry or of state- by group action. But we are eager to coöperate with you, to supplement you where you are weak and to back you up where you are strong-if only you are our men. We, the workers of the world, believe just as genuinely in science as you do. We both have some way to go in understanding the relation of science to industry and in appreciating all that coöperation may involve. But we firmly believe that if the boss will only reveal himself to his men the men will reveal themselves to the boss.

The industry for which we plan must be made dynamic every- 
where and all the time. Industry like life itself becomes static when simply reduced to formulae. Our standards must be only the bases for aggressive action. While realizing that science is making possible a measure of good-will heretofore unknown in this field, we must see in the bringing about of industrial order no getting away from the necessity for struggle and the strenuous life. But it must be a strife which will develop rather than hinder the human spirit. Let us seek first an individuality in leadership which shall bring actual responsibility and joy into every grade of work and then the encouragement of group control to the end that the cause of a genuine industrial democracy shall be advanced and production carried to new levels of enthusiasm and accomplishment. 